\title{
'The good economy': a conceptual and empirical move for investigating how economies and versions of the good are entangled
}

\author{
Kristin Asdal $^{1} \mathbb{D} \cdot$ Béatrice Cointe $^{2} \cdot$ Bård Hobæk $^{1} \cdot$ Hilde Reinertsen $^{1}$. \\ Tone Huse $^{1} \cdot$ Silje R. Morsman ${ }^{1} \cdot$ Tommas Måløy $^{1}$
}

Accepted: 1 August 2021 / Published online: 20 September 2021

(C) The Author(s) 2021

\begin{abstract}
Across Europe and the OECD, the bioeconomy is promoted as that which will succeed the carbon economy: an economy based in 'the bio' that will be innovative, sustainable, responsible and environmentally friendly. Yet how to critically approach an economy justified not only by its accumulative potentials but also its ability to do and be good? This paper suggests the concept of 'the good economy' as an analytical tool for investigating how economic practice is entangled in versions of the good. Building upon the classic contributions of Weber, Thompson and Foucault in combination with valuation studies, this paper shows how the good economy concept can be employed to examine how the economic and the good are intertwined. Empirically, the paper teases out how what is made to be good in the bioeconomy is radically different than in economies of the recent past. While 'the good economy' of the early oil and aquaculture economy concerned how to insert this economy into society in a good manner, society is surprisingly absent in the contemporary bioeconomy. The bioeconomy is enacted as an expert issue, pursued by the tools of economic valuation, and based in the unquestioned idea that 'the bio' makes any economy good.
\end{abstract}

Keywords Bioeconomy $\cdot$ Valuation studies $\cdot$ Social studies of markets · Aquaculture $\cdot$ Moral economy $\cdot$ Governmentality studies

Kristin Asdal

kristin.asdal@tik.uio.no

1 Centre for Technology, Innovation and Culture, University of Oslo, Blindern, PO Box 1108, NO 0317 Oslo, Norway

2 Centre de Sociologie de l'Innovation, Mines ParisTech, Paris, France 


\section{Introduction}

What shall we live off in the future? What will provide jobs and food, and create new markets and opportunities? What will come after the carbon economy? What will follow the fossil era? In the last ten to fifteen years, key institutions such as the OECD and the EU, as well as individual nation states, have proposed and promoted answers to these questions. They all point in a similar direction: after the fossil economy, another economy must come-a bioeconomy. In what is being proposed as the new bioeconomy, the 'bio' is being used as a shorthand for various ways in which biological materials are being enrolled in economic practices and made into the basis for the economy. As this paper will show, the various policy strategies enact the new bioeconomy in different ways, yet they all seem to share a strong normative basis: a vision of a shift to a new economy that is innovative, sustainable, responsible and environmentally friendly_in short, novel, ethical and good.

So has the economy, finally, become good? Is this, finally, an economy that will be what it now promises; ethical and environmentally friendly? Is this the economy which will enable combining growth in quantity with a growth that is also qualitatively good? Answering if the economy has finally become good is not the objective of this paper. Our aim is rather to investigate more carefully what 'the good' of the bioeconomy purports to consist of and how it contrasts with previous versions of 'the good' in the economy.

A key contribution of this paper is the concept of 'the good economy' that is developed as an analytical tool for investigating relations of the economy and the good'. This is prompted by an analysis of the emerging bioeconomy which, we argue, amounts to a reconfiguration of what a good economy purports to consist of. The analysis implies 'troubling' the good and to pursue a critical reading of the relations between 'the bio' and 'the economy' of the bioeconomy. By doing this, we simultaneously take the opportunity to explore how other versions of the economy have also been concerned with 'the good', but in other ways and formations. The paper's research strategy is to do a critical analysis of the economy 'by other means' - that has three important elements to it. Rather than critiquing how the bioeconomy is simply another turn in a capitalist logic, a new version of an already too familiar neoliberal economy, the empirical analysis of our paper aims at demonstrating how the economy can be otherwise and in fact relatively recently was otherwise - not the least when it comes to its good-economy relations. Second, and related to this, rather than taking at face value that the new bioeconomy is a normatively better (or worse) one than the economies it seeks to replace, we argue that questions of 'the good' has in fact always been entangled with the economy-but in highly different ways. The concept of 'the good economy' invites for analyses of such relations. Third, and most importantly, 'the good economy' concept enables us to grasp that there are more relations at stake in the bioeconomy than bioeconomy relations alone. Also economy-society relations are at stake, our analysis suggests. The bioeconomy is not simply about exploiting new resources or developing new tools of valuation, but, through these, about redefining the relations between the economy, society, politics and the 'bio'. 
Using the Norwegian case as our example, the paper demonstrates that whereas 'the good economy' of the early oil and aquaculture economy concerned how to insert this economy into society in a good manner, society is surprisingly absent in the contemporary bioeconomy. Rather, the bioeconomy is enacted as an expert issue, pursued by the tools of economic valuation and based on the unquestioned idea that 'the bio' makes any economy good.

So, rather than to see the new bioeconomy as a good economy, and its predecessors as essentially bad, we approach the economy with new lenses. Perhaps the current policy visions for a bioeconomy are an even more problematic and troubling way of doing the good economy than what we can detect and analyse in earlier versions of the economy? That is what this paper asks. No matter the answer, we argue that understanding these enactments and struggles and how they configure the economy differently are vital if we are to understand, but also eventually intervene in and change, economic configurations and practices.

\section{Theoretical resources and approaches to 'the good economy'}

In developing the notion of 'the good economy', we draw from a combination of the emerging field of valuation studies and social studies of markets, critical bioeconomy studies and Foucauldian governmentality studies, as well as now classical works on early capitalism in history and sociology. In contrast to the latter classical works, which sought to analyse the concrete and distinct transition to a capitalist economy in a given historical period, the notion we suggest is meant to analytically address the fact that economies are very often also about good economies. In putting this upfront as a heuristic tool, we do not only address the explicit or implicit ethical and normative dimensions of the economy. We seek to address more broadly the versions of economy that good economy relations enact-including how these versions of economies do valuations - and by what means-what we here label 'tools of valuation'. The paper argues that we need to critically engage with and scrutinize these sometimes troubling - and not always successful-versions of the good. Yet we do not put this forward simply as a critical tool, but also as a tool that may enrich and open up empirical analyses of the economy for the struggles and the versions of economy at stake. Hence, our concern is with the tools of valuation, but also more broadly with how the economy 'adds up' to distinct versions of 'the good economy'.

This article proceeds as follows: We end this introductory section with a paragraph on our empirical materials and methods. We then proceed to develop our analytical framework. First, we present the classic contributions of Max Weber and E. P. Thompson, who conceptualized the 'protestant ethic' and 'moral economy', respectively, in order to understand the emergence and effects of capitalism. We then discuss these concepts in relation to the works of Michel Foucault, thereby distinguishing what Foucault argued was a distinct dimension of the state-market formations of the neoliberal economy. From this expanded understanding of economy-normativity relations, we build the concept of 'the good economy' as a heuristic and analytical tool for investigating the ongoing discussions of the bioeconomy. This leads us to the article's empirical section, in which we employ and further 
develop our analytical framework within four key versions of economies: first, the obvious choice of the ongoing bioeconomy policy initiatives of the EU, the OECD and national governments in Europe; second, the related-but diverging-version of 'the blue bioeconomy', which is based upon ocean industries and marine resources; third, the establishment of aquaculture as an industry in Norway in the 1970s and fourth, the establishment of a petroleum industry in Norway, also in the 1970s. After this empirical exposé, we draw together the different versions of the economy and conclude by discussing how the concept of 'the good economy' may better help us make sense of co-existing forms of bioeconomies and their diverging modes of enacting the good-and ultimately, how this also carries implications not only for bioeconomy relations but also for biosociety relations.

The empirical material which forms the basis of this article is in-depth analysis of policy-related documents from the OECD, the EU and Norway. This entails a broad mapping of relevant documents within the bioeconomy field, a close analysis of a selection of these documents and the contrasting of these documents with historical examples from Norway. These historical contrasts serve to cast light on the contemporary in that they enable us to better see and grasp what we too easily take for granted. It also sensitizes us to how the different economies enact economy-society relations, bioeconomy relations, values and normativities differently. The analysis of the early aquaculture economy and petroleum economy are being teased out as versions of 'the good economy' in their own right, thus, also contributing to the paper's overarching ambition of developing versions of economies and their 'good economy' formations. This builds on a notion of 'versions of economics' or of economies developed in Asdal (2014a, b), which highlights that we are not approaching these versions as different perspectives only on one and the same reality. Instead, they are seen as realities differently enacted in various settings, where different versions can form a relational space and may contradict one another, interfere or align (cf. also Mol 1999, 2002). Further, we pursue a 'practice-oriented' approach to documents (Asdal 2015; Asdal and Reinertsen in press 2022) attuned towards analysing the relations that documents enact, the issues they produce, how documents work as tools of valuation (Asdal 2015) and how they provide space for different forms of expertise and valuation techniques.

\section{From a protestant ethic, a moral economy and market truths to 'the good economy'}

It is now more than a hundred years since the German scholar Max Weber published The Protestant Ethic and the Spirit of Capitalism, a work that has come to stand as a landmark in the analysis of modern capitalism. A key tenet of the book and his argument was, as the title indicates, the intimate interlinkages between ethics and capitalism (Weber 2001 [1904]). According to Weber, capitalism is not a non-moral enterprise; on the contrary, it is constituted upon a particular version of ethics: a work ethic inspired by Protestantism and oriented towards meticulous, diligent work, not for the purpose of showing off that the work paid off in expensive lifestyles or conspicuous consumption, but for the purpose of profit-and the re-investment of 
that profit - as an end in itself. Interestingly, it is not the economy itself which is good, but the surplus value which is constantly produced and re-invested-read as a sign that people pursuing profit are morally good subjects.

Obviously, Max Weber is not the only scholar who has contributed influentially to how we understand economy-normativity relations. Even more so, perhaps, this is the case for E. P. Thompson who, in his seminal work on the English working class, suggested the notion of 'moral economy' to capture the tensions and conflicts emerging from the transition to a capitalist economy (Thompson 1971). Thompson's point was not to argue for a particular moral in —or integral to- the economy, nor, as in the case of Weber, an ethics spearheading the drive for surplus. On the contrary, Thompson's 'moral economy' was rather the moral of the English working class and the normativities embedded in their ways of living and doing their economy, a moral economy which was set aside and suppressed by the transformation to a capitalist economy. In this analysis, there is no space for a moral economy inside the capitalist logic, but a moral economy that can seek to counter and act as a critical force against a capitalist logic. Hence, the moral is not spearheading the economy, but is rather the economy's outside (see also Fourcade 2017).

Michel Foucault - who in his governmentality lectures (2008) included an analysis of the choreography of the neoliberal and classical liberal economy-may also be included in this list of scholars who dwell on the economy and its normativity relations. In fact, in some ways Foucault's take resembles that of Thompson: When analysing the turn to markets in liberal and neoliberal society, Foucault suggested that the market becomes its own truth, so to speak: a 'regime of veridiction', where the morals or normativities that used to be linked up with issues of exchange were replaced with market truths (Foucault 2008). In this turn to a market society there is no space for moral sentiments or economies beyond the market price, which does not make a difference between the correct price and that which is good. The market price is correct, thus, by implication also good. Foucault does not draw upon this notion of the good himself, yet it makes sense, we suggest, to understand Foucault in this way. But what happens if we start to investigate and ask more explicitly about the good and the economy entanglements that might be involved? Before moving there, let us dwell a little bit longer on a few more relevant scholarly contributions.

\section{Processes of economization versus 'versions of the economy'}

In part indebted by Foucault, in part by the pragmatism of John Dewey (1939), but perhaps most notably actor-network theory, scholars in the field of social studies of markets have analysed the processes and practices by which entities, devices and practices become economic (Callon 1998; Callon et al. 2007). Hence, rather than taking for granted that the economy is already a sphere in society, the focus is more pragmatic and concerned with how the economy is being realized in practice-in its becoming, so to speak. The notion of 'economization' has been put forward to capture this as a step-by-step process (cf. Çaliskan and Callon 2009; see also Chiapello 2015 and her work on what she captures as 'financialization'). This is a more analytically and empirically open approach than analyses that state, for instance, 
that the economy is neoliberal, or that there is a pre-given capitalist logic, or that capitalism is an 'ism'. The term 'economization' nevertheless leaves little space for exploring if and how there might be other dimensions at stake than the economical. This is despite the fact that the approach interestingly addresses how the economy is made to perform not only by way of quantifications, but also by qualificationsor rather 'qualculations' (Cochoy 2008). How may such approaches be extended towards including the qualitative in more encompassing and broadened ways? And moreover, how may such approaches also be extended to include economy-society and economy-state relations? If such extensions are not done, the approach risksdespite its agnosticism on behalf of the economy and capitalism-putting too much weight on that which is seen and conceptualized as economic. We risk not providing space for the possibly extra-economical, for concerns that are collective and must be treated collectively or, for instance, politically.

While this approach has proved most fruitful in studying markets and processes of economization, the concepts developed for studying the economic in the making may leave us poorly equipped to investigate relations between what is economic and what remains external to this economy. How, for instance, can we study the relations to a 'society' or a state in which a process of economization occurs-not simply as society economized, but in its constitutive interrelations? A key dimension to Foucault's analyses was indeed that of always including such interrelations: The governmentalities and governmental technologies that he traced and analysed were profoundly linked up with state formations-not the state in a given definition though, but as an 'entity' being profoundly shaped and remade in relations, for instance, to the market. Hence, policy programmes and the art of government are key, in his analyses, to grasping the formation of the economy-and again, not in a straightforward fashion, as that of proclaiming, for instance, the existence of a neoliberal economy or a given definition of the state. The investigative method Foucault worked by does not allow for predefined grand or universal categories in this way (Asdal 2020). Instead, Foucault was constantly seeking to grasp how practices take part in transforming the categories we thought we knew the composition of.

In Foucault's analysis of the neoliberal, his constant focus is on the market-not the market in and of itself, however, but rather how (in the case of the neoliberal) the state becomes modelled, as he argues, upon the market: The market becomes the model for the state (Foucault 2008). Foucault's innovative analyses and conceptual work-especially his thesis of 'governmentalities' and his analyses of the turn to markets (that of how the markets became 'organized for collective concerns', to put it with Frankel et al. 2019)—have made tremendous impact on scholarly debates. When Foucault lectured on what he coined governmentality and biopolitics in the late 1970s, it was as if he already sensed the larger market turn which was to 'fall upon' so many national contexts during the ensuing years. Thus, his analyses gave almost immediate meaning and became a key for interpreting the new economic and societal conditions of the market society (Barry et al. 1996; Burchell et al. 1991). Also regarding studies of how life and the new life sciences are made part of the economy in the pursuit of surplus, Foucault's analyses have been a major source of inspiration (see, for example, Cooper 2008; Yoxen 1981; Rose 2007; Rajan 2006). Regarding the latter, the inspiration does not only derive from Foucault's 
governmentality studies, but also and perhaps just as much from his historical analyses of the emergence of biology and classical political economy (Foucault 1970).

Something may nevertheless have escaped Foucault's attention-perhaps because this 'something' was not so easily detectable at the time? What we will suggest is that the bioeconomy - as we can trace it in the policy visions and programmes across the EU, European nation states and the OECD from the mid-1990s-is an entry point for alerting us to something new. This 'new' is precisely about the economy's entanglements with 'the good'. The issue, then, is not simply a market turn and the market as the regime of veridiction, a truth of its own. What we are witnessing, we suggest, is another and indeed more complex configuration, or set of configurations: The new economy is in need of justification beyond its contribution to surplus and on top of its eventual success at the market. And it is this economy's relation with 'the good' that we need to trace and trouble. In pursuing this task, Foucault's practice-oriented, profoundly relational and conceptually inventive investigative method may serve as the inspiration just as well as his substantive claims in his lectures in the late 1970s.

As we will show, the bioeconomy carries a series of distinct and unique configurations between 'the good' and the economy. But what is evident for the bioeconomy also serves as an entry point for exploring how former and other versions of the economy have also carried distinct configurations of good economy relations. Searching for and exploring such configurations in former versions of the economy is one way of grasping both the promises and troubles of the bioeconomy. In analysing how the economy is essentially also about the extra-economical, the major contributions by Weber and Thompson have been and still are vital. Weber's protestant ethic is arguably a key to the spirit of capitalism, and to the drive for surplus and its re-investments, hence, to the very establishing of capitalism in the first place. Thompson's moral economy, however, is one less entangled with the economy-or with capitalism, to be precise. The moral economy is that which lies outside capitalism. And it is in this way that the term has been taken further in other and broader societal contexts; that of detecting and arguing for how various communities are morally ordered (for example, Kohler 1994). In contrast, what we suggest is a conceptual move that neither limits itself to ethics or 'morals', nor leaves questions of the normative or 'the good' to that which resides only outside the economic or capitalist realms.

The concept of 'the good economy' is intended to work in precisely this way. So let us address this suggested conceptual move and tool more directly and in more detail. Charis Thompson, in her book Good Science (2013), points to how contemporary science is entrenched in ethics and, thus, needs to be analysed and managed accordingly. Ethics can no longer be treated alongside science; it must be seen as integral to it. Thompson does not expand much on the notion of 'good science', nor does she deal with economics or the economy. Our notion of 'the good economy' still takes inspiration from her term, while also addressing normativities beyond ethics. Other academic moves from within the broader field of science and technology studies may help us move in such extended directions. Care studies is one such key move that actively addresses the qualitative and the normative in medicine, health and food practices (see, for example, Mol et al. 2010; Druglitrø 2018). "What is a 
good tomato?" Heuts and Mol (2013) ask and address how quality can be engaged with and cared for in widely different registers of valuing.

In related, but not similar, ways, contributions emerging from the field of valuation studies (Dussauge et al. 2015; Muniesa 2011) are concerned with how practices of valuation are integral to the economy. So far, these contributions have not sought to analyse the economy 'at large' - that is, not analysed the more comprehensive or encompassing versions of economies that might emerge from such diverse forms of valuation practices. Furthermore, these have not addressed the economy in relation to the explicit issue of 'the good', but rather pursued the valuation approach as more of a value-neutral term, so to speak. Rather than asking which forms of the good are at stake, contributions have so far been more concerned with the forms and means of valuation that perform the economy (Muniesa 2014; see also Callon et al. 2007; Callon 1998). The concept of 'the good economy' draws from these contributions, but extends them towards analysing the choreographies and compositions of the 'versions of economies' in question (cf. Asdal 2014a) and the entanglements between the economy and 'the good'. In doing this, the question of what 'the good' is thought to consist of may be addressed directly and not only the means by which 'the good' is enacted, but also which objects are taken to perform the good, including those in need of being cared for (Asdal 2014a).

The critical bioeconomy literature (for example, Goven and Pavone 2015; Birch 2017a; Birch and Tyfield 2013) has, to a much larger degree than valuation studies and contributions within the field of social studies of markets, addressed the economy. In putting forward 'the good economy' concept, we share the ambition of delineating the composition, choreography and formation of the bioeconomy, yet we do not want to be bound up with already too familiar notions of what this formation consists of, such as 'the neoliberal' (see Birch 2019 for a problematization of the notion of 'neoliberal' bioeconomies). Rather than a label of what the economy $i s$, the 'good economy' concept is intended as an investigative tool to question and trouble the composition of the so-called bioeconomy and its entanglements with 'the good', including 'the good' that it performs and invests in.

\section{The good green bioeconomy: troubling the inherent good of the 'bio'}

The bioeconomy has, during the past decade, become the object of major policy initiatives across Europe and beyond. Of key importance in driving this momentum are the supranational institutions of the OECD and the EU, epitomized in a set of comprehensive policy documents. In these documents, both institutions envision the bioeconomy as the desired future towards which our societies should strive, and they express urgency for national policymakers and governmental agencies to help realize this vision (OECD 2009; EU 2012a, 2013, 2018a). As asserted by the European Commission in the document Innovating for Sustainable Growth: A Bioeconomy for Europe:

A strong bioeconomy will help Europe to live within its limits. The sustainable production and exploitation of biological resources will allow the production 
of more from less, including from waste, while limiting negative impacts on the environment and reducing the heavy dependency on fossil resources, mitigating climate change and moving Europe towards a post-petroleum society (EU 2012a, p. 4).

Here, the Commission envisions the bioeconomy as the means to tackle the major challenges of unsustainable resource use, fossil fuel dependency and climate change, and to move away from a society built upon petroleum. Interestingly, the bioeconomy stands out as inherently good because of its 'bio' component-since the economic activities will be grounded in the biological, they will by definition be good. Indeed, this makes the bioeconomy a most blatant example of how 'the bio' is made to stand out as 'the good', thus, ensuring by its very bio 'the good economy'. Yet, as we will now demonstrate in more detail, this assumption not only works to present a specific notion of the bioeconomy, but also to downplay deep tensions and contradictions currently embedded in the concept. In order to highlight this, we will introduce how 'the bio' is in fact radically different things in different versions of bioeconomies, thus, enabling quite radically different economies, including their transition narratives. This in turn leads us to observe that the notion of society is curiously absent in the current initiatives, making the bioeconomy a quite different policy project than were its historical predecessors.

What, exactly, is the 'bio' component of the bioeconomy, and how is 'it' expected to be and to do good? Other scholars have already noted that there exist multiple coexisting definitions of the bioeconomy (Bugge et al. 2016; Pavone and Goven 2017). The European Commission, in the above-mentioned document Innovating for Sustainable Growth: A Bioeconomy for Europe (EU 2012a), delineate the bioeconomy as follows: "The bioeconomy encompasses the production of renewable biological resources and their conversion into food, feed, bio-based products and bioenergy" (EU 2012a, p. 16). In contrast, the OECD document entitled The Bioeconomy to 2030: Designing a Policy Agenda (OECD 2009) is surprisingly different. Here, the bioeconomy is discussed interchangeably with 'biotechnology', and the document provides an influential argument for new biotechnology as an engine of economic growth (on this initiative, see Hilgartner 2007; Parry 2007). Its vision of the bioeconomy is one where "biotechnology contributes to a significant share of economic output" (OECD 2009, p. 22). Economic growth and innovation on the basis of biotechnology and the life sciences is, thus, what drives OECD's version of the bioeconomy. In other words, what distinguishes this economy as 'bio' is not a shared resource base from biological and non-fossil inputs, but rather a base of biological knowledge, biotechnology and the life sciences.

Despite proposing overlapping policy prescriptions, the two institutions hence define and operationalize the 'bioeconomy' in most different ways. This in turn enables actors to adopt diverging versions and to modify these further within their specific context. The Norwegian government's bioeconomy strategy (NFD 2016) may serve as a case in point. By understanding the bioeconomy as "value creation based on production and exploitation of renewable biological resources in contrast to non-renewable carbon" (NFD 2016, p. 13, our translation), the Norwegian strategy is clearly based in the biomass definition rather than the biotech definition. The biomass definition carries 
strong implications for how natural resources are viewed-as biomass and a substitution for fossil inputs. This narrative of transition by substitution away from fossil inputs entails that increased utilization of biomass in itself is desirable because it represents a step towards realizing the bioeconomy-thus, 'the good economy' by implication. The biotechnology version, on the other hand, relies on a different logic: Biotechnology promises to be good because it decouples economic growth from constraining limits by harnessing the regenerative or reproductive capabilities of life itself. Thus, the biomass and biotech versions of the bioeconomy value 'the bio' that is to take part in the future bioeconomy very differently_yet they both take for granted 'the bio' as the good.

Similarly, while all the bioeconomy policy documents emphasize the need to expand the 'bio' component of the economy-whether biomass or biotech - they diverge in how they position themselves vis-à-vis fossil fuels and the petroleum economy. As noted above, the EU documents explicitly envision a post-petroleum society: "Greater use of renewable resources is no longer just an option, it is a necessity. We must drive the transition from a fossil-based to a bio-based society, with research and innovation as the motor" (EU 2013, p. 4). The bioeconomy strategy is in itself a response to this, since, as it itself states, "[a] strategy is also needed to ensure that fossil fuels are replaced with sustainable, natural alternatives as part of the shift to a post-petroleum society" (EU 2013, p. 2).

The Norwegian bioeconomy strategy (NFD 2016) similarly adopts a clear transition narrative, but rather than highlighting the need to move away from fossil fuels, what is emphasized is rather what the bioeconomy moves toward. The strategy opens by stating that it realizes that the bioeconomy is "central for the transition toward a low-emission economy" (NFD 2016, p. 5). This economy is further characterized as having a strong potential for value creation, more efficient use of renewable biological resources, new growth, a 'green shift' within the economy, increased competitiveness for Norwegian industries and firms, cross-sectoral policy initiatives and interdisciplinary research and innovation (NFD 2016, p. 5). The OECD, in its attention to the potential of biotechnology, stresses the importance of incentives to "reward environmentally sustainable technologies" and the "use of renewable biomass" (OECD 2009, pp. 6, 8), but does not explicitly adopt a transition narrative. Rather, it indicates some potentially more controversial sides of realizing the bioeconomy: "disruptive and radical technologies ... may lead to the demise of firms and industrial structures, creating greater policy challenges, but they can also result in large improvements in productivity" (OECD 2009, p. 16).

In these diverging versions of the bioeconomy, there are clearly great inherent tensions. Yet in the documents themselves, these are not addressed or acknowledged - neither in the founding documents from the supranational institutions, such as the OECD and the EU, nor in the national documents in which these versions are bound together, such as the Norwegian bioeconomy strategy. They all take for granted that making the economy 'bio' is inherently good. Furthermore, these documents stay within the bioeconomy relation and do not address how these tensions might play out in society at large. It is precisely this feature of the bioeconomy documents that we need to trouble. In order to better grasp this dimension, it is necessary to expand our empirical scope and contrast the bioeconomy documents with other similar policy initiatives that conceive of 'the good' in other ways. 


\section{The good blue economy: enabling a fully economized nature by bringing in economics and its 'tools of valuation'}

Alongside what we may summarize as the green bioeconomy discussed above, there exists a notion of a blue bioeconomy concerning the ocean industries. These policy initiatives are interchangeably termed 'blue growth' (EU 2012b), 'the blue economy' (EU 2014), 'the ocean economy' (OECD 2016, 2019), or simply 'the blue bioeconomy' (EU 2018b). Although the green and blue bioeconomies initially developed as parallel strands of policy, they are increasingly merging, as illustrated by the EU's revised bioeconomy strategy from 2018, in which "unlocking the potentials of oceans and seas" is put forth as one of three main dimensions of the European bioeconomy (EU 2018a, p. 1). Yet the notion of the blue bioeconomy offers a different conception of 'the good' than that of the green versions. A first key difference is the role of fossil fuels and petroleum production. While we showed above that the 'transition by substitution' argument is a strong narrative within the green bioeconomy, the opposite is the case in the blue bioeconomy. Both the EU's Blue Bioeconomy initiative (2018b) and the OECD's Ocean Economy project $(2016,2019)$ include all existing ocean-based industries, of which offshore petroleum is a key contributor. In the case of Norway, where the petroleum industry is indeed the nation's largest offshore industry, the government's Ocean Strategy explicitly states that "[t]he ocean industries are part of the bioeconomy" (NFD and OED 2017, p. 73, our translation).

The second key difference is also the most striking feature of the blue bioeconomy: the efforts made herein to delineate and calculate its potential economic value. As expressed by the OECD, if the oceans are explored, monitored, governed and exploited in the best possible way, we may, in 2030, have realized a 'trillion-dollar ocean' (Jolly and Stevens 2016). This numerical growth potential has set the agenda in both national and international contexts (for the national example of Norway, see the above-mentioned 'Ocean Strategy' (NFD 2016); for an international example, see the United Nations' High-level Panel on Building a Sustainable Ocean Economy (The Ocean Panel 2020); for detailed analysis of this point, cf. Reinertsen and Asdal 2018). While fostering growth has indeed been a key preoccupation of all the 'blue documents' from the EU's Blue Growth strategy onwards (EU 2012b), the OECD's Ocean Economy project went further than conventional estimates of potential industrial growth. Being based in the OECD's Futures Project and employing policy foresight techniques, it sought to advance the methods for assessing potential industrial growth by integrating the value of the ocean's ecosystems directly into the calculation. More specifically, what the OECD sought to calculate was the value of 'ecosystem services', understood as the contributions by nature to human life and society. Hence, economic capital and natural capital were made commensurable and integrated into the same economic model. The method promises to demonstrate how environmental degradation of the ocean will negatively impact not only nature as such, but also the growth potential of the ocean economy-its very size. Unsustainable growth will, thus, diminish not only the ocean's 'bio value', but also its financial value. Hence, co-calculating the value of natural capital and financial capital, the OECD asserts, will enable us to take better care of the ocean and its resources, since 
overexploitation will affect the value of ecosystems negatively and thereby in effect reduce the ocean's economic potential. The means to do so is to make the so far noneconomized nature integral to the economy quantifiable and calculable in economic terms. In short, nature is taken into account by bringing it into a regime of accounting (Asdal 2008); it is being economized (Çaliskan and Callon 2009).

Although seemingly new and innovative, this version of economization is based upon relatively well-established neoclassical economics, of which the model for taking nature into account has historically proven highly difficult to realize in practice (Asdal 1998; for discussions of related practices of valuation of nature, see Asdal 2008; Fourcade 2011; Chiapello 2015). Moreover, when reading the OECD report more closely, it becomes apparent that even the effort of calculating the ecosystem services in the first place-hence the very procedure of economizing-creates trouble and represents unresolved challenges (Nebdal 2019). The OECD's proposed new calculative tool is nevertheless put forth as the key to a transformed and more sustainable economy (OECD 2016; EU 2018b). The hopes, then, that are being invested in these 'tools of valuation' are that economic growth will be balanced up correctly against the long-term gains of conservation due to the deployment of a complex series of price-setting mechanisms. The promise then is that the tools of valuation of economics will secure that nature is being ascribed the correct price. Hence, nature is brought into economics and, simultaneously, is becoming an issue for economics and economists. Thus, the ocean economy is also becoming an expert issue. In fact, the ocean economy will become good only insofar as these 'tools of valuation' of economics are put to use. Moreover, the economy is good only insofar as nature is being economized. 'The good economy' is a fully economized nature.

The OECD approach to the blue bioeconomy is characterized by this effort to take nature into account in a manner that, in theory, discourages unsustainable overexploitation and mismanagement of the oceans. That of not preserving the services provided by nature's ecosystems is turned into a risk-for the economy. As such, the ocean economy of the OECD is an economy in which the issue of pursuing economic growth is extended from that of engaging in industrial activities for short-term gain, to also include the conservation of ecosystems for long-term gain. Another blue economy report, this time from the Norwegian context, offers a particularly strong example of how the promise of economizing future bio-values may be used, not to preserve ecosystems, but to leverage political will for rapid, large-scale industrial growth. In 2012, a report titled Value Created from Productive Oceans in 2050 calculated the Norwegian marine industries to have the potential of at least a fivefold growth in value creation by the year 2050 (SINTEF 2012). The report was commissioned by two Norwegian scientific academies and was prepared by a working group with members from academia, industry and the Research Council of Norway, while the research organization SINTEF_- one of Norway's largest-functioned as its secretariat. We highlight this report because its promise of grand growth proceeded to act almost immediately upon governmental policy: It was quoted on the opening page of a white paper on Norway's ambitions for expanding the seafood industry (MFC 2013, p. 8), and subsequently endorsed by Parliament (PNP 2013, p. 18). Several high-level politicians have since repeatedly affirmed their commitment to fulfilling this potential (for detailed analysis, see Reinertsen and Asdal 2019). 
Similar to the ocean economy report of the OECD, this report also works by a set of 'tools of valuation'. Yet the precise tools of valuation at work are different, as they rely not on neoclassical economics, but rather on a toolbox of business school models and strategies. In short, this entails, in practice, a loose combination of value chain analysis and SWOT analysis ('SWOT' being the acronym of 'strengths, weaknesses, opportunities, threats', which is what this tool seeks to identify for the project or enterprise in question). Furthermore, the very definition of 'value creation' enacts the blue economy as an enterprise, rather than a part of the national economy. Concretely, the report explicitly defines value creation "synonymously with turnaround or revenue from sales generated by the marine sector", rather than "contribution to GDP" (SINTEF 2012, p. 14), which is the definition used by the Ministry of Finance. What these business strategy tools in combination enable is to imagine a formidable future growth that also incorporates in its very calculative process the challenges and preconditions that might serve as barriers to its realization. This fascinating feature rests on an intricate calculative manoeuvre on the textual level. Quite concretely, what the report does is to first explicate future 'opportunities' and 'threats' for the marine industries (including the opportunity of expanding global markets and the threats of climate change, pollution from the aquaculture industry itself and lack of enough feedstuff), and then imagine what the growth might be like in the year 2050 if the threats are overcome. This is done by reformulating the threats into 'criteria for growth'. In the case of aquaculture, the report states that, "provided the aforementioned criteria are met, it may be possible to achieve production levels for salmon and trout of 5 million tons in 2050" (SINTEF 2012, p. 46). This effectively amounts to a fivefold growth, yet with a built-in assumption that the major threats identified by the same report have already been resolved. In effect, then, qualitative challenges and risks are built into the calculation, yet subsequently decoupled from the quantified growth potential. In effect this means that high risk and grave problems do not reduce the growth potential-quite the contrary. Paradoxically, the potential financial values are expanding when the bio-values are conceived as under pressure.

However, not only are the distinct tools of valuation different here from the OECD version of the blue economy. It also invokes a mode of policymaking and governmental action characterized by 'will and determination' to act:

[W] e believe that now is the time that politicians in Norway, to a greater extent than in the past, and much as they did for the oil and gas industry, commit themselves to the development of future marine-based industries so that we can generate greater value from the resources to which we already have access. We are seeing only the start of what can actually be exploited from the oceans by means of value generating activities, and we need political will and determination if we are to grasp the opportunities before us (SINTEF 2012, p. 12).

In appealing to politicians to 'commit themselves' and help 'grasp the opportunities' of the ocean, the report here echoes longstanding tropes from business school curricula that leaders should be bold, take risks and dare to act in the face of uncertainty (Dewing 1930, in Muniesa 2011; Doganova and Eyquem-Reynault 2009). Again, the blue economy is here enacted as a business issue and politicians are cast 
as investors in the enterprise (Reinertsen and Asdal 2019). This, in sum, enables policies for massive growth. Hence, in the context of the Norwegian contemporary blue economy, 'the good economy' is not simply an economy fully economized, but one that acts like an enterprise and has the politicians act as its investors as well as its managers. Interestingly, neither the OECD's ocean economy nor the Norwegian version provides space for the political in a conventional sense, instead turning the challenges to be either economics (finding the right price) or business (knowing the value and acting bravely). Neither of them provide space for political procedure, politics or societal concerns.

\section{The good aquaculture economy: justifying expansion by staying small and local}

The bioeconomy is often portrayed as something new, as an economy that will follow the economy of the present and the longstanding carbon economy. Obviously, this story can be told very differently. For centuries, 'the bio' has been key to growth and prosperity. In Norway, for instance, the export of timber and fish has been vital to the national economy. For the Norwegian case, aquaculture in the form of salmon farming was taking shape in the 1970s-precisely the enterprise that is today often presented as a flagship in the new, blue bioeconomy. In the early 1970s, the optimism and eagerness to invest in this new industry was 'second only to oil' along the coast, as stated in a 1973 parliamentary debate about how the authorities might aid, or reign in, its further development (PNP 1973a, p. 443). However, the growth of this new sector of the economy was, for all its promise, not simply regarded as good news pure and simple. Different models of aquaculture development-in terms of scale, geographical location or ownership —were judged very differently. Indeed, the first decisive action taken by (a unanimous) Parliament in 1973 was to limit the possibilities for an industrial path of growth in fish farming, by making any further expansion contingent upon production licences, with a maximum volume per fish farm (PNP 1973b).

A Norwegian Official Report (NOU) on aquaculture was completed in 1977, a report that is widely regarded as foundational for Norwegian fish farming and its regulation and support by the state. In continuation of the initial limitations on large, centralized units, the report devoted a short chapter to explicate the aims of Norwegian aquaculture:

1. to make use of the country's resources in order to increase food production,

2. to maintain existing jobs and habitation, increase employment and provide opportunities for a more diverse basis for livelihoods [næringsgrunnlag] in districts with weak productive or commercial activities [næringsliv],

3. to build a rational trade, providing practitioners with income comparable to what is achieved in other trades (Ministry of Fisheries 1977, p. 24). 
Making 'rational use' of the possibilities, the report states, was a 'matter for society as a whole'. The aims of the new venture, then, were articulated to fit within overall societal aims, reflecting a politically sanctioned version of a good society. Thus, this growing, new sector of the economy is justified by reference to the overall aims it should help fulfil, and the ways it might fit together with and complement already existing activities: increased food production, rural development and new opportunities specifically directed to vulnerable, coastal districts, and lastly, employment and wages comparable to fisheries and agriculture. For aquaculture to help achieve such aims, it needed to be developed in a certain way: industrial growth - understood as large, mechanized units and 'external' capital—was curtailed in favour of smaller, geographically dispersed labour-intensive fish farms with local ownership and locally available labour and natural resources. Growth itself was a potential problem to be controlled-first, in terms of the size of individual fish farms, but also in terms of the total national production volume, which risked outpacing demand, with price collapse. The first clause in the legislation ensuing from the public report states controlled growth to be a key purpose for the granting of licences: "that expansion takes place such that production stands in a reasonable relation to possible sales [omsetningsmuligheter]" (PNP 1981, p. 7). 'Reasonable' expectations dictated a steady, controlled expansion, to not overwhelm export markets abroad and to fit a new and profitable venture into remote, coastal communities at home. Hence, the growth of aquaculture in this period needed to be adjusted toand justified in terms of - an overall politically sanctioned vision of societal aims. The claim to be good was anchored in the ability to be brought into harmony with such aims.

Before drawing these indeed quite different versions of 'the good economy' together, let us first move towards the version that has come to be seen as the bad and the ugly of economies, namely the oil economy. And let us again draw on the Norwegian example, demonstrating how this version of the economy was indeed also deeply and explicitly about the good-however, in a radically different way than the current bioeconomy policy documents and strategies.

\section{The good oil economy: fostering 'a qualitatively better society'}

In 1969, international oil companies struck oil on the Norwegian continental shelf. This major reservoir inaugurated the 'oil age' and what is often referred to as the 'oil adventure' of Norway. Yet, at the time of discovering oil, Norwegian politicians were cautious that the potential new wealth would not automatically be positive for Norwegian society and its economy. In other words, the oil economy was not necessarily a good economy: the good economy had to be crafted. In 1970, a unison Norwegian Parliament articulated "Ten Oil Commandments", in which core principles of Norwegian oil policy were established (cf. Table 1). Most important of these were 'national government and control' over the exploitation and distribution of petroleum resources and revenues. The commandments, thus, explicitly state a 
Table 1 The Norwegian parliament's "ten oil commandments" (PNP 1970), translated from the Norwegian original in Reinertsen 2016, p. 154

The Norwegian Parliament's “Ten Oil Commandments” (1970)

The committee wishes to express

that national governance and control must be secured for all activities on the Norwegian continental shelf;

that the petroleum discoveries are exploited such that Norway becomes as independent as possible of others with regards to the supply of crude oil;

that there are developed new business activities with a basis in petroleum;

that the development of an oil industry must take place with the necessary concern for existing business activities and the protection of nature and the environment;

that the burning of exploitable gas on the Norwegian continental shelf may not be accepted, with the exception of shorter periods of testing;

that petroleum from the Norwegian continental shelf should as a general rule be brought ashore in Norway with the exception of single instances where sociopolitical concerns serve as a foundation for a different solution;

that the state will be engaged on every purposeful level and contributes to a coordination of Norwegian interests within Norwegian petroleum industry and to the build-up of a Norwegian integrated oil community with a national as well as international perspective;

that there will be established a state oil company that may maintain the state's commercial interests and have a purposeful cooperation with domestic and foreign oil interests;

that there north of the $62 \mathrm{nd}$ latitude will be chosen a pattern of activities that accommodates the special sociopolitical concerns facing this region;

that Norwegian petroleum discoveries to a larger extent may expose the Norwegian foreign policy to new tasks

strong moral stance: these resources belong to the nation and should be governed in the nation's best interests.

The strong moral connotations of the Ten Oil Commandments were operationalized and further explicated in the following years. In 1973, the Norwegian government issued a white paper which explicitly warned that uncontrolled use of the oil revenues would have severe consequences for Norwegian society and its economy. Thus, interestingly, the oil economy could turn into a bad economy, if not dealt with in a proper way. In order to avoid this, the government asserted that petroleum activities must contribute to building a qualitatively better society:

The petroleum discoveries in the Northern Sea make us richer as a nation. The Government holds that one first and foremost must use the new possibilities to develop a qualitatively better society. One should avoid that the result only entails a quick and uncontrolled expansion in the use of material resources without society at large being considerably changed. The guidelines that are drawn up for the petroleum activities and the use of revenues must therefore be part of a planned transformation of Norwegian society. [...] Democratic institutions must gain actual government [herredømme] of the development in increasingly more areas. The economic possibilities must be used to create increased equality in standards of living and in other ways to prevent social problems and to develop a more environmentally and resource-friendly production. The welfare society must be further expanded and the composition of 
private consumption must be influenced through an active consumer policy.

Local communities must be strengthened and developed with a view to a better environment as a whole (Ministry of Finance 1974, p. 6, italics in original, our translation).

Integral to the white paper's vision of a good society-one of social equality, strong local communities and paid work for all-is an active government. In practice, the white paper envisioned the newfound petroleum riches to enable shorter working days, expanded welfare services and the inclusion of new groups into the workforce. The petroleum revenues would not ensure this on their own. Quite the contrary, the white paper repeatedly asserts that the infusion of oil into the economy might produce multiple "problems of transition" (Ministry of Finance 1974, p. 6). The oil might easily become a negative force, a bad economy, if the industry were allowed to grow unchecked and too quickly, and if the revenues were spent through unleashed consumer spending. In our own words: If the oil economy was to become a good economy, on the contrary, it had to be built wisely and determinately into society. The white paper's key concern was to outline how a smooth and beneficial transition into an oil economy might be done. The key measures for doing so were to ensure a 'moderate tempo' of exploration and production, to commission Norwegian companies and train Norwegian employees in the new sector, to build local communities around the new installations and to channel revenues abroad through investments and sales (Ministry of Finance 1974, pp. 8-10, 15). In this way, the economy would be spared multiple pressures-upon prices, salaries, employment and domestic mobility.

The white paper, thus, expressed a deeply ambivalent view of the expected growth and repeatedly underlined its potential problems, should it be allowed to unfold too quickly. It is cautious and tempered with respect to the potential benefits, and urges restraint. The policies must be in place to ensure that the coming growth and transition is becoming a positive force. What the white paper never doubts, however, is the growth itself. It will come: the question is how to control it in order to ensure that it fosters a "qualitatively better society" (Ministry of Finance 1974, p. 6). If the coming oil economy is governed in an active, deliberate manner, it might become 'a good economy'. It will never automatically be good-it must be made into a good economy, through the determined policy and government of a social democratic nation state.

\section{Drawing versions of 'the good economy' together}

As we now know, the oil economy turned into a critically bad economy, but in a quite different way than what was envisioned in its infancy: today, the oil economy stands out as essential to move away from in order to establish an economy that is more environmentally friendly and, most importantly, not destroy the world's climate. The bioeconomy, as we saw, presents itself as an economy that will do precisely this: provide an alternative to the carbon economy. However, the contrasts with these other versions of the economy_-such as the oil economy and the early phases of the 
aquaculture economy - also help to highlight other differences between these economies and policy initiatives. One of these is how the bioeconomy differs not only in its 'bio'-'economy' relation, but just as importantly in its 'economy'-'society' relation. Whereas the early oil and aquaculture economies were problematized in terms of how these new economic activities were being inserted into society, society does not exist in the same way in the policy documents on the bioeconomy. Rather than an economy inserting itself into society, the bioeconomy is oriented towards inserting 'the bio' into the economy.

Interestingly and importantly, this insertion of 'the bio' into the economy is not envisioned to happen by societal means, but by way of the tools of valuation of economics, either neoclassical economics, such as ecosystem services, or business school models and strategies. This is in itself an important feature of the bioeconomy in both its green and blue versions. Even more so, the bioeconomy is presented as if such insertions come without frictions and dilemmas. The bioeconomy is enacted as if it is unproblematic in itself, and as if the bioeconomy relation is without tension, as the 'bio' is made to stand out as the essentially good. This stands in sharp contrast to the oil economy of the 1970s which actively pointed at and discussed problems and conflicts of interest that were likely to arise as this new economy was making its impact on society. The new oil economy could become a good economy - a 'qualitatively better society' could be the result of it-yet this economy-society relation had to be actively steered and governed since the opposite could just as well be the consequence, if society did not have its hand on the process. Similarly, the early aquaculture enterprise had to justify itself according to the societal gains it could eventually contribute to fulfil. The active governing of this new economy was key. Modesty and staying small was enacted as a precondition to its becoming a good economy.

We have already pointed out how 'the good' of the bioeconomy is conceived as given in the 'bio' itself. While comparing and contrasting with other versions of the economy, what becomes apparent is how society is curiously lacking in the bioeconomy policy programmes. But so also is an explicit discussion of dilemmas, tensions and conflicts that arise as old and new versions of 'the bio' are to be made integral to the economy - and indeed also society more broadly. How to explain this absence of the political and the societal? One way of explaining it is precisely by addressing how realizing 'the good economy' is turned into a calculative endeavour, thus, essentially also an expert challenge. Hence, rather than an issue of how to insert the economy into society and by which tools and means, the issue becomes simply that of employing the right tools of valuation-of economics. Moreover, this version of the good economy is one where 'the bio'- the nature upon which the bioeconomy rests-is fully economized, thus, transformed into an economic object. As we saw, the blue bioeconomy of the OECD was a prominent example of this.

Also, the Norwegian version of the blue economy rests upon tools of valuation from economics-yet, in this case, business methods and calculative strategies, including narrative strategies. Interestingly, whereas society is apparently lacking in the OECD version, this is a version in which the state is modelled upon the enterprise and politicians are cast as investors encouraged to be bold on behalf of 
the enterprise. Hence, whereas Foucault, in his governmentality lectures, identified how the state in the neoliberal society was modelled upon the market, this is something new and different: rather than being modelled upon the market, the state is being modelled upon the enterprise. 'The good economy' is, thus, not so much a straightforward market economy, but rather an enterprise society. And interestingly, if this observation is correct, the point is not so much that there is no society in which the economy is to be inserted, or that the moral economy resides outside of the economy, but that there is no moral economy outside of the enterprise: society and the enterprise are merging into one.

\section{Conclusion}

The overriding objective of this paper is to suggest a recasting of the bioeconomy, most notably by putting forward the notion of 'the good economy' as an analytical working tool made for opening up and investigating this economy further. Here we return to Max Weber as a source of inspiration: working conceptually was precisely Weber's suggested method. In The Protestant Ethic and the Spirit of Capitalism, the argument was that even if a concept was already put forward at the very beginning of a study (in Weber's case, the notion of a distinct 'spirit of capitalism'), an eventual precise definition of the proposed concept could only be substantiated step-by-step as the study was moving forward, and thus, only be defined at the study's very end (Weber 2001 [1904]). Importantly then, methodswise, Weber's aim was not "to grasp historical reality in abstract general formulae but in concrete genetic sets of relations which are inevitably of a specifically unique and individual character" (Weber 2001 [1904], pp. 13-14). Weber noted that such conceptual moves would always have an individual tone; analysing the relevant phenomena from the chosen viewpoint would never be the only possible alternative, as others could always see these phenomena differently. And rather than working from a precise definition at the start of the study, the conceptual innovation is more a way of envisioning the relevant phenomenon-what Weber formulated as "a provisional description" (Weber 2001 [1904], pp. 13-14), and which may also be linked to his famous concept of 'ideal types' (Weber 2012).

'The good economy' is our point of departure in a quest for grasping the emerging bioeconomy and the normativities involved. The bioeconomy is often presented as something radically new-an economy that will come and must come after our current economy. Ironically, however, one could argue the other way around - that bioeconomies are the oldest of all economies, the economy that we have and currently also still heavily rely on. So the newness, we suspect, is not so much in itself an economy that relies on the biological, but how the relation between the 'bio' and the 'economy' is envisioned and enacted. Furthermore, and as a more overriding point, the newness seems related to the normativities that are involved: the bioeconomy steps forward as a new form of good economy-as the 'good economy'. This is also why, we suggest, we need this conceptual innovation as our tool to work with. 
However, the concept of the good economy is not put forward in order to analyse the bioeconomy exclusively. This conceptual move is done in order to work as a heuristic tool for analysing good economy relations more broadly, and also in other versions of the economy. The economy has always also been about interrelations with the good, and we need approaches and tools to also investigate that which is 'extra-economical', as well as 'the good' that is being performed as integral to the distinct versions of economy at stake. In doing so, we also need to include the 'tools of valuation' that are involved in doing such good economy relations. Hence, we need to continue studying practices and processes of economization and financialization. Yet we also need to expand such endeavours with the study of how the good resides in such practices, which versions of economies are performed by these, how the good economy can also take radically different shapes and be more of an issue about collective concerns, and how the economy can be inserted into society in good ways.

Acknowledgements The manuscript is composed of original material that is not under review elsewhere, and the study(ies) on which the research is based has been subject to appropriate ethical review. There are no competing interests, intellectual or financial in the research detailed in the manuscript.

Funding This work was supported by the European Research Council (ERC) under the Grant 637760 and by the Norwegian Research Council under the Grant 301733.

\section{Declarations}

Conflict of interest The authors have no conflict of interest in relation to the research behind this paper.

Open Access This article is licensed under a Creative Commons Attribution 4.0 International License, which permits use, sharing, adaptation, distribution and reproduction in any medium or format, as long as you give appropriate credit to the original author(s) and the source, provide a link to the Creative Commons licence, and indicate if changes were made. The images or other third party material in this article are included in the article's Creative Commons licence, unless indicated otherwise in a credit line to the material. If material is not included in the article's Creative Commons licence and your intended use is not permitted by statutory regulation or exceeds the permitted use, you will need to obtain permission directly from the copyright holder. To view a copy of this licence, visit http://creativecommons.org/licen ses/by/4.0/.

\section{References}

Asdal, K. 1998. Knappe ressurser? Økonomenes grep om miljøfeltet [Scarce resources? The economists' hold on the environment]. Oslo: Scandinavian University Press.

Asdal, K. 2008. Enacting things through numbers: Taking nature into account/ing. Geoforum 39 (1): $123-132$.

Asdal, K. 2014a. From climate issue to oil issue: Offices of public administration, version of economics and the ordinary technologies of politics. Environment and Planning A 46 (9): 2110-2124.

Asdal, K. 2014b. Versions of milk and versions of care: The emergence of mother's milk as an interested object and medicine as a form of dispassionate care. Science in Context 27 (2): 307-331.

Asdal, K. 2015. Enacting values from the sea: On innovation devices, value practices, and the co-modification of markets and bodies in aquaculture. In Value practices in the life sciences and medicine, ed. I. Dussauge, C.-F. Helgesson, and F. Lee, 168-185. Oxford: Oxford University Press. 
Asdal, K. 2020. Foucaults metode og nyliberalismen: Eller skal vi heller snakke om den grenseløse innovasjons $\varnothing$ konomien? [Foucault's method and neo-liberalism. Or should we rather discuss the limitless innovation-economy?] Agora 37 (03-04) 2020.

Asdal, K. and Reinertsen, H. (in press 2022). Doing document analysis. A practice-oriented method. London: SAGE Publications.

Barry, A., T. Osborne, and N. Rose, eds. 1996. Foucault and political reason: Liberalism, neo-liberalism and rationalities of government. London: Routledge.

Birch, K. 2017a. The problem of bio-concepts: Biopolitics, bio-economy and the political economy of nothing. Cultural Studies of Science Education 12 (4): 915-927.

Birch, K. 2017b. Rethinking value in the bio-economy: finance, assetization, and the management of value. Science, Technology, \& Human Values 42 (3): 460-490.

Birch, K. 2019. Neoliberal bio-economies? The co-construction of markets and natures. Cham: Springer International Publishing.

Birch, K., and D. Tyfield. 2013. Theorizing the bioeconomy: Biovalue, biocapital, bioeconomics or... what? Science, Technology, \& Human Values 38 (3): 299-327.

Bugge, M.M., T. Hansen, and A. Klitkou. 2016. What Is the bioeconomy? A review of the literature. Sustainability 8 (7): 691.

Burchell, G., C. Gordon, and P. Miller, eds. 1991. The Foucault effect: Studies in governmentality. Chicago: University of Chicago Press.

Çaliskan, K., and M. Callon. 2009. Economization, part 1: Shifting attention from the economy towards processes of economization. Economy and Society 38 (3): 369-398.

Callon, M., ed. 1998. The laws of the markets. Oxford: Blackwell.

Callon, M., Y. Millo, and F. Muniesa, eds. 2007. Market devices. Oxford: Blackwell Publishing.

Chiapello, E. 2015. Financialisation of valuation. Human Studies 38 (1): 13-35.

Cochoy, F. 2008. Calculation, qualculation, calqulation: shopping cart arithmetic, equipped cognition and the clustered consumer. Marketing Theory 8 (1): 15-44.

Cooper, M. 2008. Life as surplus: Biotechnology and capitalism in the neoliberal era. Seattle: University of Washington Press.

Dewey, J. 1939. Theory of valuation. Chicago: University of Chicago Press.

Doganova, L., and M. Eyquem-Renault. 2009. What do business models do? Innovation devices in technology entrepreneurship. Research Policy 38 (10): 1559-1570.

Druglitrø, T. 2018. 'Skilled care' and the making of good science. Science, Technology, \& Human Values 43 (4): 649-670.

Dussauge, I., C.-F. Helgesson, and F. Lee, eds. 2015. Value practices in the life sciences. Oxford: Oxford University Press.

EU. 2012a. Innovating for Sustainable Growth: A Bioeconomy for Europe. Directorate-General for Research and Innovation, European Commission, https://publications.europa.eu/en/publicationdetail/-/publication/1f0d8515-8dc0-4435-ba53-9570e47dbd51. Accessed 15 October 2020.

EU. 2012b. Blue Growth: Opportunities for Marine and Maritime Sustainable Growth. Communication from the Commission to the European Parliament, the Council, the European Economic and Social Committee and the Committee of the Regions, COM(2012) 494 final, https://ec.europa.eu/marit imeaffairs/sites/maritimeaffairs/files/docs/publications/blue-growth_en.pdf. Accessed 15 October 2020.

EU. 2013. A Bioeconomy Strategy for Europe: Working with Nature for a More Sustainable Living. Directorate-General for Research and Innovation, European Commission, https://publications. europa.eu/en/publication-detail/-/publication/26b789d4-00d1-4ee4-b32e-2303dfd2207c. Accessed 15 October 2020.

EU. 2014. Innovation in the Blue Economy: Realising the Potential of our Seas and Oceans for Jobs and Growth. Communication from the Commission to the European Parliament, the European Economic and Social Committee and the Committee of the Regions, COM(2014) 254 final/2, https://eur-lex. europa.eu/legal-content/EN/TXT/PDF/?uri=CELEX:52014DC0254R(01)\&from=EN. Accessed 15 October 2020.

EU. 2018a. A Sustainable Bioeconomy for Europe: Strengthening the Connection Between Economy, Society and the Environment. Directorate-General for Research and Innovation, European Commission, https://ec.europa.eu/research/bioeconomy/pdf/ec_bioeconomy_strategy_2018.pdf\#view=fit\& pagemode=none. Accessed 15 October 2020.

EU. 2018b. Blue Bioeconomy: Situation Report and Perspectives. Report from European Market Observatory for Fisheries and Aquaculture Products (EUMOFA) and Directorate-General for Maritime 
Affairs and Fisheries, European Commission, http://www.eumofa.eu/documents/20178/84590/ Blue+bioeconomy_Final.pdf. Accessed 15 October 2020.

Foucault, M. 1970. The order of things: An archaeology of the human sciences. New York: Pantheon Books.

Foucault, M. 2008. The birth of biopolitics: Lectures at the Collège de France, 1978-1979. Basingstoke: Palgrave Macmillan.

Fourcade, M. 2011. Cents and sensibility: Economic valuation and the nature of 'nature.' American Journal of Sociology 116 (6): 1721-1777.

Fourcade, M. 2017. The fly and the cookie: Alignment and unhingement in 21st-century capitalism. Socio-Economic Review 15 (3): 661-678.

Frankel, C., J. Ossandón, and T. Pallesen. 2019. The organization of markets for collective concerns and their failures. Economy and Society 48 (2): 153-174.

Goven, J., and V. Pavone. 2015. The bioeconomy as political project: A polanyian analysis. Science, Technology, \& Human Values 40 (3): 302-337.

Heuts, F., and A. Mol. 2013. What is a good tomato? A case of valuing in practice. Valuation Studies 1 (2): $125-146$.

Hilgartner, S. 2007. Making the bioeconomy measurable: Politics of an emerging anticipatory machinery. BioSocieties 2 (3): 382-386.

Jolly, C. and B. Stevens. 2016. The Trillion Dollar Ocean. OECD Insights Blog, http://oecdinsights.org/ 2016/04/27/the-trillion-dollar-ocean/. Accessed 15 October 2020.

Kohler, R.E. 1994. Lords of the fly: Drosophila genetics and the experimental life. Chicago: University of Chicago Press.

MFC. 2013. Meld. St. 22 (2012-2013). Verdens fremste sjømatnasjon. Ministry of Fisheries and Coasts. Bergen: Fagbokforlaget.

Ministry of Finance. 1974. Meld.st. nr. 25 (1973-74). Petroleumsvirksomhetens plass i det norske samfunn. [The petroleum industry's place in Norwegian society], https:/www.regjeringen.no/contentass ets/695b71fb157043998a9643f72b3ed843/stm197319740025000dddpdfs.pdf. Accessed 04 September 2020 .

Ministry of Fisheries. 1977. NOU 1977: 39 Fiskeoppdrett. Norges offentlige utredninger [Norway's public reports]. Oslo: Universitetsforlaget.

Mol, A. 1999. Ontological politics: A word and some questions. In J. Law and J. Hassard (eds), ActorNetwork-Theory and After. Malden, MA: Blackwell.

Mol, A. 2002. The body multiple: Ontology in medical practice. Durham, NC: Duke University Press.

Mol, A., I. Moser, and J. Pols. 2010. Care in practice: On tinkering in clinics, homes and farms. Bielefeld: Transcript Verlag.

Muniesa, F. 2011. A flank movement in the understanding of valuation. The Sociological Review 59 (s2): 24-38.

Muniesa, F. 2014. The provoked economy: Economic reality and the performative turn. Oxfordshire: Routledge.

Nebdal, S. 2019. Å gjфre havet $\phi$ konomisk: Verdsettingspraksiser for $\phi$ konomisering av havet og dets $\phi k o-$ systemer. Masters thesis. Oslo: University of Oslo.

NFD. 2016. Kjente ressurser - uante muligheter. Regjeringens bioфkonomistrategi [Known resources, untold opportunities. The government's bioeconomy strategy]. Ministry of Trade, Industry and Fisheries, https://www.regjeringen.no/contentassets/32160cf211df4d3c8f3ab794f885d5be/nfd_biook onomi_strategi_uu.pdf. Accessed 15 October 2020.

NFD and OED. 2017. Ny vekst, stolt historie. Regjeringens havstrategi [New growth, proud history. The government's ocean strategy]. Ministry of Trade, Industry and Fisheries and Ministry of Petroleum and Energy, https://www.regjeringen.no/contentassets/097c5ec1238d4c0ba32ef46965144467/nfd_ havstrategi_uu.pdf. Accessed 15 October 2020.

OECD. 2009. The Bioeconomy to 2030: Designing a Policy Agenda. Main Findings and Policy Conclusions. OECD report, https://www.oecd.org/futures/long-termtechnologicalsocietalchallenges/42837 897.pdf. Accessed 15 October 2020.

OECD. 2016. The Ocean Economy in 2030. OECD report, http://www.oecd.org/sti/futures/the-oceaneconomy-in-2030-9789264251724-en.htm. Accessed 15 October 2020.

OECD. 2019. Rethinking innovation for a sustainable ocean economy. OECD report, http://www.oecd. org/publications/rethinking-innovation-for-a-sustainable-ocean-economy-9789264311053-en.htm. Accessed 15 October 2020.

Parry, B. 2007. Cornering the futures market in 'bio-epistemology.' BioSocieties 2 (3): 386-389. 
Pavone, V., and J. Goven. 2017. Introduction. In Bioeconomies: Life, technology, and capital in the 21st century, ed. V. Pavone and J. Goven, 1-12. Cham: Springer International Publishing.

PNP. 1970. Proceedings of the Norwegian Parliament. Innst. S.nr. 294 (1970-71), The Norwegian Parliament's 'Ten Oil Commandments'.

PNP. 1973a. Proceedings of the Norwegian Parliament. Stortingsforhandlinger 1972-73, Od.td.

PNP. 1973b. Proceedings of the Norwegian Parliament. Stortingsforhandlinger 1972-73, Innst. O. nr. 57.

PNP. 1981. Proceedings of the Norwegian Parliament. Stortingsforhandlinger 1980-81, Ot. prp. nr. 30.

PNP. 2013. Proceedings of the Norwegian Parliament. Stortingsforhandlinger 2012-13, Innst. 418 S.

Rajan, K.S. 2006. Biocapital: The constitution of postgenomic life. Durham: Duke University Press.

Reinertsen, Hilde. 2016. Optics of Evaluation: Making Norwegian Foreign Aid an Evaluable Object, 1980-1992. PhD Dissertation. University of Oslo.

Reinertsen, H., and K. Asdal. 2018. Ikke lenger uberegnelig og uregjerlig? Visjoner om et kalkulerbart, produktivt og bærekraftig hav i politiske dokumenter [No longer unpredictable and unruly? Visions of a calculable, productive and sustainable ocean in political documents]. Arr. Idéhistorisk Tidsskrift 3-4: 3-17.

Reinertsen, H., and K. Asdal. 2019. Calculating the blue economy: Producing trust in numbers with business tools and reflexive objectivity. Journal of Cultural Economy 12 (6): 552-570.

Rose, N. 2007. The politics of life itself. Princeton: Princeton University Press.

SINTEF. 2012. Value Created from Productive Oceans in 2050. A report prepared by a working group appointed by the Royal Norwegian Society of Sciences and Letters (DKNVS) and the Norwegian Academy of Technological Sciences (NTVA), https://www.sintef.no/contentassets/f025260af6 b8435394eced5e03939e11/value-created-from-productive-oceans-in-2050.pdf. Accessed 15 October 2020 .

The Ocean Panel 2020 (The High Level Panel for a Sustainable Ocean Economy). Transformations for a Sustainable Ocean Economy. A Vision for Protection, Production and Prosperity. Washington DC: World Resources Institute. https://oceanpanel.org/ocean-action/files/transformations-sustainableocean-economy-eng.pdf. Accessed 06 May 2021.

Thompson, C. 2013. Good science: The ethical choreography of stem cell research. Cambridge: MIT Press.

Thompson, E.P. 1971. The moral economy of the English crowd in the eighteenth century. Past \& Present 50 (1): 76-136.

Weber, M. 2001 [1904]. The protestant ethic and the spirit of capitalism. London: Routledge.

Weber, M. 2012. The 'objectivity' of knowledge in social science and social policy. In Collected methodological writings, ed. M. Weber, H.H. Bruun, and S. Whimster, 100-138. London: Routledge.

Yoxen, E. 1981. Life as a productive force: Capitalising the science and technology of molecular biology. In Science, technology and the labour process, ed. L. Levidow and R. Young, 66-122. London: Blackrose Press.

Publisher's Note Springer Nature remains neutral with regard to jurisdictional claims in published maps and institutional affiliations.

Kristin Asdal Historian and Professor of Science and Technology Studies (STS) at TIK, University of Oslo. PI of project funded by the European Research Council (ERC): Enacting the Good Economy. Biocapitalization and the little tools of valuation (grant agreement no 637760) and PI of ValueThreads (grant agreement no 301733).

Béatrice Cointe Chargée de Recherche CNRS (UMR 9217-i3) working on laboratory methods in market studies and economics.

Bård Hobæk PhD candidate at TIK with a project on the history and politics of aquaculture (grant agreement no 637760).

Hilde Reinertsen Researcher at TIK with a project on qualitative methods and the marine bioeconomy (grant agreement no 637760). 
Tone Huse Associate professor at TIK and UiT The Arctic University of Norway with a project on the politics and practices in the bioeconomy and the economic life of the Atlantic cod (grant agreement no 637760).

Silje R. Morsman PhD candidate at TIK working with responsible research and innovation in the life sciences in the COMPARE project, funded by UiO:Life Science.

Tommas Måløy PhD candidate at TIK with a project on publishing and data practices in the life sciences. 